\title{
Conservative treatment results of 39 patients with adolescent idiopathic scoliosis
}

\author{
H Yilmaz ${ }^{1 *}$, T Kuru $^{2}$ \\ From 8th International Conference on Conservative Management of Spinal Deformities and SOSORT 2011 \\ Annual Meeting \\ Barcelona, Spain. 19-21 May 2011
}

\section{Background}

Scoliosis conservative treatment's goal is to maintain function, and prevent symptoms in the short and longterm and protect the health related quality of life. The purpose of this study was to analyze our conservative treatment results.

\section{Materials and methods}

39 patients with AIS who did received a conservative treatment method included in the study allocated into three groups. 35 of our patients were female and 4 were male. 4 patients with $20^{\circ} \geq \mathrm{Cobb}$ angle enrolled into first group (exercise group). 24 patients did not want to receive an exercise programme so they included in 2 . group (brace group). All of the patients worn CAD/ CAM system-Chêneau-brace.11 patients in the 3. group worn brace and participated outpatient exercise pro- gramme. The mean 3 months changes - Treatment resultsof three groups were analysed with SPSS.

\section{Results}

There were significant within-group pre-post treatment improvements of Cobb angle for brace and brace+exercise group. Analyses showed no significant differences in other parameters (see Table 1).

\section{Conclusion}

In the conservative treatment of AIS, making the right decision about patient, brace and exercise is very important.

Our study have some limitations, our follow up time was short and we did not have enough patients in each group so we could not compare groups results.

Table 1 Treatment results after 3 months

\begin{tabular}{lllll}
\hline Treatment groups & Variables & Before treatment Mean \pm SD & After treatment Mean \pm SD & P value \\
\hline Exercise and brace group (n:1 1) & Max Cobb & $34.38 \pm 9.24$ & $29.37 \pm 10.86$ & 0.024 \\
& Vertebral rotation $^{\circ}$ & $10.63 \pm 5.67$ & $9.57 \pm 5.62$ & 0.162 \\
& Rib Hump $^{\circ}$ & $15.55 \pm 9.70$ & $11.66 \pm 8.01$ & 0.120 \\
\hline Brace group (n:24) & Max Cobb $^{\circ}$ & $34.00 \pm 8.56$ & $28.60 \pm 10.24$ & $\mathbf{0 . 0 0 0}$ \\
& Vertebral rotation $^{\circ}$ & $8.82 \pm 4.59$ & $7.21 \pm 4.46$ & 0.072 \\
& Rib Hump $^{\circ}$ & $24.18 \pm 14.62$ & $19.25 \pm 12.76$ & 0.328 \\
\hline Exercise group (n:4) & Max Cobb $^{\circ}$ & $20.56 \pm 3.00$ & $19.28 \pm 1.00$ & 0.664 \\
& Vertebral rotation $^{\circ}$ & $5.50 \pm 1.29$ & $4.52 \pm 2.12$ & 0.205 \\
& Rib Hump $^{\circ}$ & $4.00 \pm 6.92$ & $4.26 \pm 3.54$ & 0.653 \\
\hline
\end{tabular}

${ }^{1}$ Canakkale Onsekiz Mart University PMR Department, Canakkale, Turkey

Full list of author information is available at the end of the article 


\section{Author details}

${ }^{1}$ Canakkale Onsekiz Mart University PMR Department, Canakkale, Turkey.

${ }^{2}$ Istanbul University, School of Physical Therapy and Rehabilitation, Istanbul, Turkey.

Published: 27 January 2012

doi:10.1186/1748-7161-7-S1-047

Cite this article as: Yilmaz and Kuru: Conservative treatment results of 39 patients with adolescent idiopathic scoliosis. Scoliosis 2012 7(Suppl 1): O47.

Submit your next manuscript to BioMed Central and take full advantage of:

- Convenient online submission

- Thorough peer review

- No space constraints or color figure charges

- Immediate publication on acceptance

- Inclusion in PubMed, CAS, Scopus and Google Scholar

- Research which is freely available for redistribution 